\title{
Religious Education and Religious Value in The Coastal Community (Case Study of Karangsong Village Fishermen Community of Indramayu District - Indonesia)
}

\author{
Ta'rif ${ }^{1}$, Munawiroh $^{2}$, Achmad Dudin $^{3}$ \\ \{ta75rif@gmail.com ${ }^{2}$, mun.asrori@gmail.com ${ }^{1}$, achmad.dudin@gmail.com ${ }^{3}$ \} \\ Researchers in Training and Development Center of Religious Education, \\ Ministry of Religious Affairs-Indonesia
}

\begin{abstract}
The aim of this paper is to obtain data and information on Karangsong Village fishing community portraits (religious, demographic, socio-cultural, and religious education), the form of religious education services in the fishing communities of Karangsong village, and government policies and community participation on religious education to the fishing communities of Karangsong Village. Techniques of collecting and analyzing data will use observation or observation techniques, and interviews, while data analysis of this research is descriptive-analytical. The result shown that the religious commitment of the fishermen in the Karangsong area in running the teachings of Islam, and practices outside of Islam that tend toward syncretism. Thanks to the existence of religious education institutions, residents or local residents began to realize the importance of education, especially religious education. The nature of gotong royong as a culture of rural communities is continuously maintained and implemented, not only for social activities but also for religious activities.
\end{abstract}

Keywords: Education, Fisherman Community, Indonesia, Religious.

\section{Introduction}

The life of the fishing community is categorically different from that of other communities, such as peasant communities or traders. The difference is seen not only in the lifestyle and mindset, but also on their cultural and religious values. Therefore, it is natural that the reality of the beliefs of the fishing community depends on the sea, for example, the conception of the existence of extraordinary power in the sea that can not be separated from the life of fishermen communities in this country.

In Indramayu, precisely in the village of Karangsong, similar religious practices also occur. However, since the ongoing process of Islamic dissemination and institutionalization, most fishing communities have embraced Islam. History notes that many of the wali are spreading Islam using various instruments of art so that later born Islam is mixed with local traditions.

Similarly, in Java, the spread of Islam in Indramayu is one of them that departs from the coast and continues to give influence to the interior [1]. For example, Sunan Gunung Djati who spread Islam through the media of local art. This resulted in a process of attraction between local cultures and outside cultures. Not infrequently, this process produces the cultural dynamics of 
local communities. Therefore, it is not surprising that in the life of coastal societies there are practices of syncretism and / or cultural acculturation, such as performing rituals in Islamic teachings, yet still trusting local beliefs.

The rituals of local tradition are passed down from generation to ancestor, such as a sea party or Nadran, burning incense before going to sea, using certain amulets to strengthen the physical and so are some local traditions believed by the fishermen to be able to add blessings. They believe that there is an unseen supernatural power that they cannot visualize, but they really believe in it. Such facts lead the authors to examine further how religious communities' religious commitments lie between the interrelations of Islam and local culture, and further explore their response to social change.

Based on the above description, the focus of this research would like to get data and information portrait of fishermen community of Karangsong Village (religious, demography, socio-culture, and religious education), how to make religious education service to fisherman community of Karangsong village (who conducts, the implementation, and how the results, and government policies and community participation on religious education to fishing communities of Karangsong Village.

\section{Method}

The approach in this research is using qualitative research approach. The research objects are clearly described and thoroughly analyzed in accordance with the existing theoretical framework. While in the technique of collecting and analyzing the data will use observation or observation techniques, and interviews, while the analysis of this research data is descriptiveanalytical, ie data that has been collected through research is described and analyzed for research problems can be systematically and directedly answered.

\section{Result and discussion}

\subsection{Description}

From the study of Geertz and other writers who followed, coastal communities in general have prominent features. In terms of religious ideology, the majority of Islamic "santri", in terms of language etiquette, are relatively harsh; in communicating tend to be straight forward, and in terms of work orientation, more prominent in the choice of being "entrepreneur". In relation to Indramayu culture, coastal communities are not categorized as Muslim "santri" [4]. Instead, they tend to confuse religion with local traditions or commonly called syncretism [2]. Based on Glock's description of the religious dimension, the religious commitment of the fishing community can be seen from the five dimensions, ie the ideological, practical, experiential, intellectual and effect dimensions. In addition, there are also some supporting variables in researching their religious commitments, such as religious organization affiliation, belief doctrine, ritual type, and ritual frequency.

Data presented by head of Karangsong village, total population in 8987 Karangsong villages with 3500 family heads. Karangsong village condition is relatively better compared to other coastal villages because it is quite close to the city, and in the village is being developed Mangrove Tour, so that the community already contaminated with urban culture. Facilities in Karangsong Village are also relatively better. There are elementary schools, mosques / 
mosques, and madrassas, currently seem to be being built by SMK Marine. In terms of economy and fisherman's house has been better. The encouraging thing is the existence of Traditional Fishermen Union (SNT), an organization that fights for the rights of fishermen. The organization is chaired by Kajidin. He said that Karangsong fishermen began to realize the importance of an organization. Similarly, in terms of education, the fishermen have started to realize to send their children to school, although on the way a few drops out of school for helping parents go to sea.

The social and cultural structure of the community of Karangsong village is famous for its extremely violent character. This is not without cause, but because their lifestyle is very dependent on nature. In the north coast of Java, where most of the population works to catch fish, some of the catch is consumed for home use or sold entirely. Usually the fishermen's wife will take a role in the business of buying and selling fish and responsible for taking care of domestic household. There are several characteristics that we can see from Karangsong residents who mostly live as fishermen, namely: (1) Daily increments cannot be determined because the amount of income depends on the season and the fisherman's own status; (2) The education level of the fishermen is reduced so that no other work can be done besides continuing the work as fisherman; (3) Fishermen, more related to the economy of exchange and production are not related to staple food. This means that fishery products are easily damaged and must be marketed immediately; (4) The capital of the fishery requires a large and risky investment compared to the agricultural sector. While the fishermen in the village of Karangsong most of them do not have their own boat, they hire to a merchant who controls the fishermen of Karangsong village; (5) Income earned every day by fishermen is also caused by the limited family members who directly participate in the production factor; (6) The religious style tends to local Islam; they respect more informal leaders such as kyai than government officials.

The characteristics have been ingrained in the fishing life of Karangsong village. Although in certain seasons fishing income is very high but in subsequent seasons the income of fishermen is very small even none. Fishermen also have a consumptive lifestyle. According to Mr. Casman (fishermen) at a time when their income is high their consumption patterns are also high. However, when their low income they kept survived by selling their valuables or debts with very high interest rates. These accounts payable are very unhealthy. Interest offered by the owner of the money of $20-50 \%$ if paid with fixed time. If there is a late payment will be in a fine fined by agreement. This is what causes the fishermen to remain in the poverty line. Besides the poverty factor in Karangsong village.

The existence of mangrove tourism, also greatly help the economy of the community of Karangsong village. Many young men and women who take the opportunity to earn or increase family income by selling drinks and food for tourists who want to enjoy the beauty of mangrove forest. Even the parents also do not want to miss, with their boats take the tourists to the mangrove forest at a cost of 20-30 thousand / person. Visitors on Saturday / Sunday reach 100 people. Therefore, Karangsong village, as described above, is the best coastal village compared to other coastal villages in Indramayu.

The local traditions that are still believed by some of the villagers of Karangsong are: nadran, asking smart people, using talisman for physical strengthening, chanting / chanting, blessing in blessing of guardians and parents, and offerings at the crossroads during the night of Friday and evening "takbiran". 


\subsection{Spreading and institutionalization}

History of the spread of Islam in Indramayu is not separated from the history of spreading Islam in Cirebon. In running his government, Sunan Gunung Djati uses a decentralized system. The pattern of power of the Islamic Kingdom of Cirebon using the pattern of Coastal Kingdom, where the port has a very important role with the support of the hinterland into a vital supporter. Programs that run in leading governance in Cirebon, according Sunarjo (1983) is the intensity of development of Islam to all corners of the Tatar Sunda, including to Indramayu.

After developing economic forces, Sunan Gunung Djati as head of government manages the government both in the center and in the nagari areas. To smooth the government, the Sultan placed relatives and ulama-ulama as elements of government leadership both central and local. Recognizing the position of Cirebon as a center for the spread of Islam, the center of political power, as well as a very strategic economic center, then Sunan Gunung Djati accelerate the development of the city. For that matter, he is in a relationship with the Islamic Empire of the North Coast of Java, namely the Islamic Demak Kingdom [5]. In da'wah, Sunan Gunung Djati communicates with local culture. He uses the media of art, such as wayang, rudat, berokan, and goods. The spread of Islam was also done in the 19th century when some of Indramayu's children were put into pesantren in Buntet, Kempek, Cirebon. This also happens to the coastal communities of Indramayu.

Therefore, Islam in Indramayu came, developed and institutionalized in the archipelago through a long process. The struggle in the Islamization process in the archipelago, at least produce four theories [3]. First, the G.W.J Drewes theory stated that Islam came from the Indian subcontinent. Second, the theory which states that Islam came from Bengal, expressed by S.Q Fatimi with the discovery of headstone Fatimah bint Maimun. Third, the theory that Islam came to Indonesia through Colomader and Malabar.

Finally, the theory that Islam came from its original source, is Arab. Meanwhile, regarding the time of arrival, there are two opinions. Some are claiming in the 8th century Miladiyah One hijriah, and there are those who claim that Islam came to Indonesia in the 13th century when the Islamic kingdoms developed politically. Meanwhile, just around the 15th century Islam touched Indramayu. The spread of Islam in Indramayu cannot be separated from the services of Prince Cakra Buana or Walangsungsang or Mbah Kuwu Sangkan from Cirebon. Furthermore, the spread of Islam is continued by Sunan Gunung Djati, the nephew of Prince Cakra Buana.

\subsection{Religious and religious education service}

\subsubsection{Forms of religious education services}

In Indramayu itself the number of people who are predominantly Islamic and Islamic abangan have been classified advanced rapidly associated with religious education institutions and religious. Recorded number of educational institutions, especially Karangsong village already has the following educational institutions. 
Table 1. Number of Islamic religious education institutions.

\begin{tabular}{lcl}
\hline \multicolumn{1}{c}{ Name of institution } & Total & \multicolumn{1}{c}{ Total of santri } \\
\hline Madrasah Diniyah Takmiliyah Awaliyah & 3 & 483 \\
TPQ & 9 & $10-15$ stundents/institution \\
Majelis Taklim & 7 & $25-30$ jamaa/institution \\
\hline
\end{tabular}

\subsubsection{Madrasah diniyah takmiliyah}

Madrasah Diniyah is one of the institutions of religious education on the outside of the school that is expected to be able to continuously provide Islamic education to students who are not fulfilled in the school path that is given through the classical system and apply the educational level: Madrasah Diniyah Awaliyah (4 yr), Wustho (2 yr), and Ulya (2 yr).

Under the Education Law and Government Regulations, Madrasah Diniyah is an integral part of national education to fulfill the public's demand for religious education. Madrasah Diniyah belongs to institutionalized education and aims to prepare learners in the mastery of Islamic religious knowledge.

In Karangsong village there are 3 Madrasah Diniyah Takmiliyah Awaliyah (MDTA), MDTA Nurul Hikmah I and MDTA Nurul Hikmah II, and MDTA that serve population aged $7-13$ as many as 1013 people. If calculated based on the basic education APK $125 \%$, while APS $65.5 \%$ and APM is $55.5 \%$.

In terms of services aspect and demension Madrasah Diniyah Takmiliyah Awaliyah in the implementation there are 9 aspects that become supporters, between one aspect with other aspects of course must synergize and support each other.

1) The founder of Madrasah Diniyah Takmiliyah Awaliyah in Karangsong village is to fulfill the aspirations of karangsong villagers and built by community leaders who are concerned about religious education in karangsong village;

2) Its management is fully granted to the community even though the founder is the highest element of leadership;

3) Educators and Education Personnel, are not composed of professional ustadz, but they only provide teaching and education according to their knowledge, ability and free time and the students are not determined his age. Teachers are drawn from citizens; they have backgrounds of S1 and Madrasah Aliyah (MA) graduates;

4) The students / santri-satrinya come from piutra-daughter villagers of Karangsong village community;

5) Curriculum and materials taught using curriculum compiled by the Ministry of Religious Affairs;

6) The teaching method is done conventionally by way of lecturing, writing and reading;

7) Facilities and infrastructure, student chairs, desks, chairs, cabinets, blackboards and cabinets are very limited, prepared by the institution itself, there has been no interference from the local government. In addition, there is a mushalla in the courtyard;

8) School operational costs and teacher salary according to the narrative of diniyah head Nurul Hikmah, obtained or sourced from santri contribution of ten thousand rupiah, and part of the honorarium given by the Ministry of Religious Affairs [6].

\subsubsection{TPA and TPQ}

The Qur'an Educational Park (abbreviated TPA / TPQ) is an institution or community group that organizes non-formal Islamic religious education which aims to teach the reading of the Qur'an from an early age, and to understand the basics of Dinul Islam in park age children 
children, elementary school and or madrasah ibtidaiyah (SD / MI) or even higher. TPA / TPQ is equivalent to and kindergarten (Kindergarten), where the curriculum is emphasized on providing the basics of reading the Qur'an as well as helping the growth and spiritual development of children in order to have readiness in entering furthereducation.

In Karangsong village there is one mosque and nine mushalla, that is where the implementation of TPA and TPQ or they call it with Movement of Reading, Writing, Understanding, Practicing and Socializing Al-Qur'an, started since 1995. Numbers of santri participate between 10-15/ institution. The aspects and dimensions that support the service are as follows:

1) The TPA / TPQ originator is a citizen who cares about the importance of reading and writing Al-Qur'an;

2) The management of the TPA / TPQ is also in empowerment with local community members;

3) Most of their teachers are mosque / mushalla administrators or community members who have concern (volunteering) to teach;

4) The sisters come from the sons and daughters of the local community (Karangsong);

5) The material taught is a basic understanding of reading and writing the Qur'an, which includes reading and writing the Qur'an with the Tajwid and the lessons of the stories in the Qur'an;

6) The curriculum used is left entirely or depends on the teaching that is ustadz and ustadzahnya. However, some refer to the curriculum of the Ministry of Religious Affairs $[6]$

7) The teaching method in reading tartile with writing practice;

8) Means used in the form of mosques / mosques and some are built next to the mosque but still in one area of the mosque;

9) Source of financing according to the narratives Religious figures, as well as clerical TPA / $\mathrm{TPQ}$, obtained from voluntary santri contributions, and salaries of teachers some are sourced from Religious Affair Ministry honor ustadz and ustadzah.

\subsubsection{Taklim assembly}

Taklim Assembly has a sense of gathering place for someone to study knowledge (especially religious knowledge). Assembly Ta'lim when viewed from the organizational structure, including non-formal educational organizations are non-formal educational institutions, because it is not supported by a set of academic rules of Taklim Assembly also much highlighted for its role in developing an Islamic person to the participants. but even so the function of majelis taklim itself is very felt in society [8].

The purpose of the taklim assembly, may formulation vary. Because the founders of the assemblies taklim with environmental organizations, and different congregations, never menimatkan goal. Then, Dra. Hj. Tutty Alawiyah AS, in his book "Da'wah Strategy in the Environment of Taklim Assembly ", formulates the purpose in terms of its function, namely: First, serves as a place of learning, the aim of the taklim assembly is to increase knowledge and religious beliefs, which will encourage the experience of religious teachings. Second, serves as a place of social contact, hence the purpose of hospitality. Third, function to realize social interest hence the purpose to increase awareness and prosperity of household and environment jamaahnya [9].

In the village of Karangsong with 3500 heads of households, there are 7 groups of taklim assemblies, if in the average of 40 hours, then the number of 280 pilgrims, so only $8 \%$ of 
families who attend the assembly taklim, as seen in terms of aspects and demensinya, with the chairman of the assembly taklim As-Salam as follows [7]:

1) Triggered on community participation,

2) managed with the community,

3) Learning activities are held every night Ba'da Maghrib and Ba'da Isya for the Fathers. For morning activities and Ba'da dzuhur is for mothers;

4) Educators / Ustadz and Ustadzah are religious figures of local people, occasional visits from extension agents and subscribers of external mubalighs;

5) Jamaah pengajiannya consist of Fathers and Mothers local residents (Karangsong) about 25 - 40 people;

6) The material that is learned in Majlis Ta'lim includes reading, Al-Qur'an and tajwidnya, interpretation with ulum Al-Qur'an, hadith and Fiqh and ushul fiqh, monotheism, morals coupled with the materials needed by pilgrims for example the problem of child mischief. In addition, there are also rihlah (visits) and the commemoration of the Great Day of Islam;

7) The curriculum used is left entirely or dependent on Ustadz and Ustadzah which is adapted to the needs of the community,

8) The teaching method used in the form of lectures (ngga nging nging) and study of the book.

9) The facilities used are mosques and mushalls, some of which are in people's homes, and

10)The cost of organizing is obtained or sourced from the community self-help. And according to information from one of the extension workers assigned to the village, no single assembly has received any help either from the local government or the ministry of religion. (speech of Uun Fauiziyah's mother, Religion Officer).

\subsubsection{Community participation in religious education}

The existence of Religious Education Institution in Karangsong Village is inseparable from the participation of the local community. In this case the participation provided by the community is diverse. There are six forms of community participation:

1) Join the activity. Local people around $60 \%$, participate directly in the implementation of majelis taklim activities and celebrations of Islamic holidays. Major Islamic days are usually held, the Memorial of the Prophet's Mawl, the Memorial of Isra Mikraj and (some of them) Ashura Day.

2) Power. The community participates in the form of donating power, shoulder to shoulder in preparing the needs or faslilitas for the implementation of various activities in the event of the big days of Islam.

3) Shcooling of Children to LPK. Participation in the third form of the community - about $20 \%$ - of the local population, sending their children to local educational institutions, $60 \%$ of them send their children to local TPA / TPQ and $60 \%$ of the community participate in organized studies in assembly's taklim.

4) Idea / Thought. Participation in the form of donations of thought or ideas is given by certain people. In this case, only religious figures, in accordance with their scientific capacity, provide input in the execution of the Islamic High Days, not only ceremonial, but also the celebrations have an impact on the awareness and practice of community religion. Similarly, the contribution of thought to the development and improvement of religious and religious education institutions, both in physical form, the quantity of institutions and the quality of graduates from the institution.

5) Funds. For the good activities, the educational institutions or the organization of the big 
days of Islam in this village mostly collected from the aid (self-help) community.

6) Material. Participation is material donation. This form of participation usually consists of donations from donors, large boat owners and the people-people who live in the city. The owner of a large ship is a fishing entrepreneur. The village of Karangsong is a coastal area that inhabited by fishermen.

\subsubsection{Government participation in religious education}

Of the six forms of participation there are specially carried out by the government, some are done specifically by the community, and some are carried out jointly between the government and the community. Particular government-specific participation in Regulation / Policy includes:

1) Must read Al-Qur'an 15 minutes before studying public school, religion, both public and private) and 15 minutes for employees in the Office of Agencies / offices in all districts Indramayu.

2) Compulsory Education Madrasah Diniyah. This Regulation on the Reason of Madrasah is made by the government with the intention that its existence in the community becomes solid and solid teaching materials given by synergized and complements each other between formal education institution and non-formal education.

3) Entry requirements of new students must attach a diploma of MDTA. The new student requirements policy is intended to synergize between the schools under the management of the Ministry of National Education and the Ministry of Religious Affairs as well as the schools managed by the community.

4) The establishment of MDTA. Madrasah Diniyah Takmiliyah Awaliyah is essentially equivalent to basic education that specifically provides religious education. This regulation or policy needs to be developed in order to complement each other between Primary School and Madrasah Diniyah.

5) Appeal of veiling. Using jibla or hijab specifically for students whose are Muslim. However, it is necessary to use the policy of its use in a persuasive manner of selfawareness so as not to impede the students.

6) Improving Implementation Guideline of the Holy Qur'an Reading on the Flag Ceremony on Monday. The flag ceremony at the school has become the provision of every educational unit. Flag ceremonies are performed on predetermined national days. Hence the reading needs the policies or regulations governing the inclusion of the Qur'an in accordance with the nature and types of the national days.

7) Implementation guidelines for Muslim work clothes / school uniforms. This is similar to the use of hijab or hijab. For Muslims clothing must cover the aurat in accordance with the provisions of religious shari'a. The urge to use uniforms in accordance with the provisions of Islamic Shari'ah for Muslim employees, as an effort to realize the obligation to carry out his teachings. However, the most important thing is that awareness must arise from the employee concerned and the model of clothing used is in accordance with local cultural norms.

8) Formation of Assembly Taklim. Regulation or policy on the formation of Majelis Taklim is also made by the government in order to strengthen and strengthen its existence in the region.

9) Following the participation of the government in terms of cost / budget, the existence of BOS / BOM, Bea students santri, allowance teachers, religious scholars of Islam, khafidzoh, Imam Masjid and coaching MTQ. Regarding the manager of religious 
education, conducted by the community.

\subsubsection{The Role of religious organization in society}

In addition to public and government participation in religious and religious education, there is another role that is the role of religious organizations, such as Nahdlatul Ulama (NU) and Muhammadiyah.

In the village of Karangsong, religious organizations play a significant role in fostering religious life, as evidenced by cultural changes from local traditions to local Islamic traditions. Local traditions that are still believed by some villagers Karangsong like nadran (sea party) and selamatan before sea, for the role of religious leaders of these activities have included elements of Islamic ritual (pieces of verses of the Qur'an or dzikr-dzikr ummah Islam in general).

Another Islamic ritual that has seen its development is the people of Karangsong fishermen have prayed in the mosque even though the frequency is still low, reciting and helping other religious activities, but also they have sent their children in Madrasah School. Meanwhile, in the matter of obedience to perform Islamic worship, Casman revealed that most fishermen pray only one time because they go to sea.

Interestingly, casman claimed that if his ship and his group were hit by a storm, often one of the members of the group echoed the call to prayer on the ship. Although the fishermen perform syncretic sacred rites, they accept the Islamic da'wah openly. Fishermen do not mind if their children are enrolled in madrasah schools. The establishment of madrassas and mosques is actually thanks to the services of religious elites from NU and Muhammadiyah circles. Nevertheless, according to Rasidin, there will be a difference between the fishermen who run the religion of Islam, with fishermen who believe more syncretic things when tahlilan is held

Syncretic fishermen prefer to keep quiet or bring food, but not to do zikr. NU (Nahdhatul Ulama) is actually more easily accepted among fishermen because of its characteristics that compromise local traditions. There is a distinct dialectic between both of them.

\section{Conclusions}

Based on the research, can be concluded as follow:

1) Religious commitment of fishermen in Karangsong region represents characteristic of coastal community of Indramayu in general. Their commitment to follow the teachings of Islam, and practices outside of Islam that tends toward syncretism. Da'wah conducted by the guardians in Indramayu causing the acculturation of culture, which is the combination of two or more cultures that produce a new culture but still does not eliminate the characteristics of each. As a result of the acculturation of Hinduism and Islam this ultimately resulted in a mixture of Islam and local traditions. Through the cultural field, the traditional heritage is carried on from generation to generation. Looking at ideological dimensions and ritual dimensions, fishermen in the Karangsong area are more committed to running local Islamic traditions than pure Islamic rituals. Evident from the rites they do, such as nadran, using talismans, pilgrimages to the grave of guardians and the dead parents, providing offerings, and asking smart people. It is characterized by, from 3500 heads of households in the fishing village of Karangsong, only 280 heads of families are active in 
religious activities of majelis taklim and from that number they send their sons / daughters to MDA and TPA / TPA.

2) The religious commitment of fishermen society was born from the social construction built by the fishermen community itself. Even in Karangsong there is a dialectical process between Islam and local traditions, yet Islam cannot yet touch the deep depth of local culture, staying outside as a belief. That is why religious leaders are more focused on children-going to fishermen in providing Islamic teachings than parents who have constructed their own ideological dimension. In the process of social construction, the growing times, both the Karangsong people understand the historical background of why there is an interesting attraction between Islamic tradition and local tradition. This aspect is in line with the religious knowledge (intellectual dimension).

3) The more the times grew; there has been a social change in the life of fishermen in the Karangsong area, although a tradition is difficult to change. The rituals that originally breathed Hindus are now many that are gradually disappearing because access to information about Islam is better. There is a cultural change from local traditions to local Islamic traditions thanks to the actors of Islamic organizations such as NU and Muhammadiyah.

4) Citizens or locals begin to realize the importance of education, especially religious education thanks to the existence of religious education institutions in the community. The awareness of the fishermen community in this hali is marked by their active participation in the development of religious education institutions, by sending their children and children without any coercion to go to the madrasah school, or studying the TPA / TPQ, as well as community participation in the teachings held in the village of Karangsong itself although still in relatively few numbers.

5) The nature of gotong royong as a culture of rural communities is continuously maintained and implemented, not only for social activities but also for taklim activities in majelis taklim and celebrations of Islamic holy days, such as the Grand Mawlid of Muhammad Saw, Isra Mi'raj and (some) Ashura.

6) Cooperation in the development of educational institutions, and community religious life, is done by donations in the form of thought, as well as financial, according to their capacity or ability. The contribution of thought is given by certain people, local religious leaders, so that religious activity is not only ritual / ceremonial, but also affects the awareness and practice of community religion. Togetherness for religious development also appears in physical form, in order to increase the quantity of institutions and the quality of graduates from the institution.

7) However, there is still a need to get special and serious custody, such as the drunken habit of the fishermen after the sea and their pragmatic ways of achieving irrational success. In fact, the results of the effort that has been done for months can be exhausted in an instant just because it is used for gambling and spree.

Acknowledgements. This article was completed thanks to the support and assistance of all parties, therefore the author would like to thank especially the informants who were willing to provide data and information, the Head of the Center for Research and Development of Religious Education who gave confidence in conducting this research, most recently to the leadership of the journal has edited this article so that it is eligible to be published. 


\section{References}

[1] Syam, Nur : Islam Pesisir. PT LKIS Pelangi Aksara Yogyakarta, pp. 63 (2005).

[2] Thohir, Mudjahirin: Agama Masyarakat Nelayan. Semarang, pp. 1 (2007)

[3] Syam, Nur : Islam Pesisir. PT LKIS Pelangi Aksara Yogyakarta, pp. 59 (2005).

[4] Geertz, Clifford : Abangan, Santri, dan Priyayi dalam Masyarakat Jawa. PT. Djaya Pirusa: Jakarta (1983).

[5] Kantor Wilayah Kementerian Agama Provinsi Jawa Timur. Pedoman Penyelenggaraan Diniyah Takmiliyah, Tahun 2010.

[6] Kementerian Agama RI. Direktorat Jendral Pendidikan Islam, Direktorat Pendidikan Diniyah Dan Pondok Pesantren: Pedoman Penyelenggaraan Madrasah Diniyah Takmiliyah. Jakarta (2014).

[7]Muhsin MK : Manajemen Majelis Taklim. Jakarta: Pustaka Intermasa, (2009)

[8]Peraturan Menteri Agama Republik Indonesia Nomor 13 Tahun 2014. Pendidikan Keagamaan Islam. Tahun 2014

[9] Alawiyah, Tutty: Strategi Dakwah di Lingkungan Majelis Taklim. Bandung: Mizan, pp. 4. (1997), cet. I 